\title{
PENGARUH KOMPOSISI CAMPURAN SABUT DAN TEMPURUNG KELAPA TERHADAP NILAI KALOR BIOBRIKET DENGAN PEREKAT MOLASE
}

\author{
OTONG NURHILAL*DAN SRI SURYANINGSIH \\ Departemen Fisika Fakultas MIPA Universitas Padjadjaran, \\ Jl. Raya Bandung-Sumedang Km 21, Jatinangor 45363 \\ *email : otong.nurhilal@phys.unpad.ac.id
}

\begin{abstract}
Abstrak. Indonesia merupakan negara tropis yang menjadi salah satu penghasil kelapa terbesar di dunia. Dalam satu buah kelapa hanya menghasilkan daging kelapa sebesar $28 \%$, sisanya adalah sabut kelapa sebesar 35\% dan tempurung kelapa sebesar $12 \%$ yang sering dianggap sebagai limbah sisa. Salah satu bentuk pemanfaatan dari limbah sabut dan tempurung kelapa yaitu dengan dibuat menjadi briket yang dapat digunakan sebagai bahan bakar alternatif. Penelitian ini bertujuan untuk mengetahui komposisi yang optimal pada pembuatan briket campuran sabut dan tempurung kelapa dengan menggunakan perekat tetes tebu (molase). Metode yang digunakan dalam penelitian ini yaitu metode ekperimen dengan tahapan persiapan bahan, karbonisasi bahan, pembuatan briket, dan pengujian briket. Pada pembuatan briket, bahan perekat yang digunakan adalah perekat molase dengan konsentrasi $10 \%$. Pengujian yang dilakukan meliputi uji proksimat, uji nilai kalor, dan uji pembakaran dengan metode WBT (Water Boiling Test) untuk mengetahui efisiensi pembakaran. Dari hasil penelitian menunjukan peningkatan nilai kalor seiring dengan penambahan konsentrasi tempurung kelapa. Sehingga komposisi yang optimal pada pembuatan briket campuran sabut dan tempurung kelapa adalah $50 \%$ : 50\% dengan nilai kalor sebesar $6211 \mathrm{kal} / \mathrm{g}$ dan telah memenuhi Standar Briket Nasional. Dan dari hasil uji pembakaran didapatkan efisiensi pembakaran sebesar $9,861 \%$.
\end{abstract}

Kata kunci : Tempurung Kelapa, Molase, Briket, Nilai Kalor

\begin{abstract}
Indonesia is a tropical country that became one of the largest coconut producers in the world. In one coconut produce coconut meat of $28 \%$, the rest is coconut husk $35 \%$ and coconut shell of $12 \%$ which is often regarded as waste residue. One form of utilization of coconut coir waste and shell is to be made into briquettes that can be used as an alternative fuel. This study aims to determine the optimal composition of briquettes mixture of coir and coconut shell by adhesive molasses. The method used in this research is experimental method with the stages of material preparation, material carbonization, briquette making, and briquette testing. In the manufacture of briquettes, adhesives used are molasses adhesives with a concentration of $10 \%$. Tests conducted include proximate test, calorific value test, and combustion test with WBT (Water Boiling Test) method to determine the combustion efficiency. From the results of the study showed an increase in calorific value along with the addition of coconut shell concentration. The optimum composition of coconut husk briquette and coconut shell briquettes is $50 \%$ : $50 \%$ with a calorific value of $6211 \mathrm{cal} / \mathrm{g}$ and has complied with the National Briquettes Standard. And from combustion test result got the burning efficiency equal to $9.861 \%$.
\end{abstract}

Keywords : Coconut shell, Molasses, Briquettes, Heat Value

\section{Pendahuluan}

Tempurung kelapa memiliki nilai kalor yang tinggi dibandingkan dengan nilai kalor biomassa yang lainnya, yaitu sebesar 7283,5 cal/g. Biomassa dengan nilai kalor 
tinggi biasanya dijadikan sebagai basis pencampuran dalam pembuatan biobriket. Bahan campuran tambahan biasanya diambil dari limbah biomassa dengan nilai kalor rendah tetapi jumlahnya melimpah seperti sekam padi, bonggol jagung, jerami padi dan lain sebagainya. Biobriket campuran tempurung kelapa dengan biomassa lain yang sudah dibuat adalah campuran tempurung kelapa dengan serbuk kayu, menghasilkan nilai kalor 7192,15 cal/g [1], tempurung kelapa dengan serbuk kayu surain, jati dan cempaka dengan nilai kalor masing-masing $5421 \mathrm{kal} / \mathrm{g}, 5449,5$ $\mathrm{kal} / \mathrm{g}$ dan $5375 \mathrm{kal} / \mathrm{g}$ [2], tempurung kelapa dengan jerami padi dengan nilai kalor $4000-4500 \mathrm{kal} / \mathrm{g}$ dengan berbagai variasi komposisi. Nilai kalor jerami padi sebesar $1525,5 \mathrm{cal} / \mathrm{g}$ [3].

Selain tempurung kelapa, komponen lain dari kelapa adalah sabut kelapa yang biasanya menjadi limbah. Komposisi sabut dalam buah kelapa sekitar 35\% dari berat keseluruhan buah kelapa. Sabut kelapa terdiri dari $75 \%$ serat (fiber) dan $25 \%$ gabus (pitch) yang menghubungkan satu serat dengan serat yang lainnya. Komposisi kimia dari sabut kelapa terdiri dari lignin $(35 \%-45 \%)$ dan selulosa $(23 \%-43 \%)$ [4]. Biobriket dari campuran sabut kelapa yang sudah dibuat antara lain campuran sabut kelapa, tempurung kelapa, kayu dan bambu [5] Biobriket dari campuran sabut kelapa dengan batubara. [6].

Untuk memanfaatkan seluruh limbah kelapa menjadi biobriket maka dalam penelitian ini telah dilakukan pembuatan biobriket campuran tempurung kelapa dan sabut kelapanya dengan berbagai variasi kompisisi. Tujuan penelitian ini adalah mengetahui karakteristik biobrket campuran tempurung kelapa dan sabutnya yang meliputi sifat proksimat dan nilai kalor, serta mengetahui pengaruh perekat molase terhadap sifat proksimat dan nilai kalornya.

\section{Metode Penelitian}

Sabut dan tempurung kelapa yang digunakan pada penelitian ini berasal dari limbah tanpa mengetahui umur dan jenis kelapanya. Perekat yang digunakan adalah molase yang berasal dari produk samping industri pengolahan gula dalam bentuk cair. Molases memiliki kandungan protein kasar 3,1\%; serat kasar $60 \%$; lemak kasar 0,9\%; dan abu 11,9\%. Kadar air dalam cairan molase sebesar 15-25\% dan cairan tersebut berwarna hitam rasanya sirup manis. Penggunaan perekat tetes tebu (molase) pada briket menghasilkan briket arang dengan kerapatan, ketahanan tekan, kadar zat menguap dan kadar abu yang lebih besar dibanding briket arang yang menggunakan perekat tapioka [7].

Sabut dan tempurung kelapa yang sudah didapatkan kemudian dikeringkan dibawah sinar matahari selama 2 hari untuk mengurangi kadar air yang terkandung dalam sabut dan tempurung kelapa. Dari 2,7 kg sabut kelapa sebelum dikeringakan, didapatkan 2,4 kg sabut kelapa setelah dikeringkan. Sedangkan untuk tempurung kelapa, dari 3,2 kg sebelum pengeringan didapatkan 2,6 kg setelah pengeringan. Artinya kadar air yang hilang dari sabut kelapa sebesar $0,3 \mathrm{~kg}$ dan tempurung kelapa sebesar $0,6 \mathrm{~kg}$.

Setelah pengeringan, sabut dan tempurung kelapa dikarbonisasi dengan menggunakan tungku karbonisasi yang terbuat dari bahan pelat besi dengan diameter $31 \mathrm{~cm}$ dan tinggi $40 \mathrm{~cm}$. Karbonisasi dilakukan selama 4 jam. Setelah dikarbonisasi kemudian sabut dan tempurung kelapa yang sudah menjadi arang 
dihaluskan dengan ayakan ukuran 60 mesh. Selanjutnya dilakukan pencampuran arang sabut dan tempurung kelapa dengan variasi komposisi sebagai berikut :

Tabel 1. Variasi komposisi campuran sabut dan tempurung kelapa

\begin{tabular}{cc}
\hline \multicolumn{2}{c}{ Komposisi Campuran } \\
\hline Sabut & Tempurung \\
$90 \%$ & $10 \%$ \\
$80 \%$ & $20 \%$ \\
$70 \%$ & $30 \%$ \\
$60 \%$ & $40 \%$ \\
$50 \%$ & $50 \%$ \\
\hline
\end{tabular}

Proses selanjutnya adalah melakukan pencampuran dengan bahan perekat tetes tebu (molase) dengan konsentrasi 10\% selanjutnya dilakukan pencetakan. Dari variasi campuran tersebut dilakukan pengujian karakteristik yang meliputi uji proksimat dan nilai kalor.

\section{Hasil dan Pembahasan}

\subsection{Hasil Karakterisasi Arang Sabut dan Tempurung Kelapa}

Sabut dan tempurung kelapa yang telah mengalami proses pengarangan selanjutnya dikarakterisasi dengan uji proksimat untuk mengetahui kadar air, abu, zat terbang dan karbon terikat serta pengukuran nilai kalor. Berikut ini adalah hasil karakterisasi arang sabut dan tempurung kelapa tanpa perekat dan dengan perekat.

Tabel 2. Hasil Karakterisasi dari Briket Sabut dan Tempurung Kelapa

\begin{tabular}{lccccc}
\hline \multicolumn{1}{c}{ Sampel } & $\begin{array}{c}\text { Kadar } \\
\text { air }(\% \\
\text { adb })\end{array}$ & $\begin{array}{c}\text { Abu } \\
\%, \text { adb }\end{array}$ & $\begin{array}{c}\text { Zat } \\
\text { Terbang } \\
(\% \text { adb })\end{array}$ & $\begin{array}{c}\text { Karbon } \\
\text { terikat } \\
(\% \text { adb })\end{array}$ & $\begin{array}{c}\text { Nilai } \\
\text { kalor } \\
(\mathrm{cal} / \mathrm{g})\end{array}$ \\
\hline Sabut Tanpa Perekat & 6,44 & 3,93 & 34,24 & 55,39 & 5819 \\
Sabut Perekat 10\% & 6,68 & 3,86 & 34,34 & 55,12 & 5754 \\
Tempurung Tanpa Perekat & 4,69 & 2,37 & 27,3 & 65,64 & 6862 \\
Tempurung Perekat 10\% & 4,76 & 2,31 & 30,26 & 61,67 & 6542 \\
\hline
\end{tabular}

Dari Tabel 2 terlihat bahwa nilai kalor tempurung kelapa dan sabut setelah dikarbonisasi lebih besar dari non karbonisasinya yaitu $4300 \mathrm{kal} / \mathrm{g}$ untuk tempurung kelapa dan $3300 \mathrm{kal} / \mathrm{g}$ untuk sabutnya. Peningkatan ini disebabkan peningkatan nilai karbon terikat dan berkurangnya zat terbang setelah dikarbonisasi.

Dari hasil uji proksimat sampel tanpa perekat terlihat bahwa kadar air, kadar abu dan kadar zat terbang tempurung kelapa lebih rendah dari sabutnya. Sedangkan kadar karbon terikat dan nilai kalor tempurung kelapa lebih besar dari sabutnya. Hal ini disebabkan kadar selulosa, hemiselulosa dan lignin tempurung kelapa lebih besar dari sabutnya. Kadar selulosa, hemiselulosa dan lignin tempurung kelapa 
masing-masing adalah 33,61\%, 19,27\% dan 36,51\%. Terlebih setelah dilakukan karbonisasi selulosa, hemislulosa dan lignin tempurung kelapa dan sabutnya akan terurai seiring dengan besarnya temperatur karbonisasi.

Jika dilihat dari pencampuran perekat, pembeian perekat berpengaruh terhadap penurunan kadar karbon terikat dan nilai kalor masing-masing sampel. Hal tersebut disebabkan karena perekat tetes tebu mengandung kadar air yang cukup tinggi yang mengakibatkan nilai kalor yang dihasilkan menjadi turun.

\subsection{Analisa Briket Campuran Sabut dan Tempurung Kelapa}

Arang sabut dan tempurung kelapa dicampurkan dengan konsentrasi yang telah ditentukan dan dilakukan penambahan bahan perekat molase dengan konsentrasi $10 \%$ untuk dikarakterisasi. Hal tersebut dilakukan untuk mengetahui campuran yang optimal pada pembuatan briket campuran sabut dan tempurung kelapa, Berikut ini adalah hasil karakterisasi briket campuran sabut dan tempurung kelapa.

Tabel 3. Hasil karakterisasi briket campuran tempurung kelapa (TK) dan sabut (S)

\begin{tabular}{cccccc}
\hline $\begin{array}{c}\text { Sampel } \\
\text { (Perekat 10\%) }\end{array}$ & $\begin{array}{c}\text { Kadar air } \\
(\% \text { adb })\end{array}$ & $\begin{array}{c}\text { Abu } \\
\%, \text { adb }\end{array}$ & $\begin{array}{c}\text { Zat } \\
\text { Terbang } \\
(\% \text { adb })\end{array}$ & $\begin{array}{c}\text { Karbon } \\
\text { terikat }(\% \\
\text { adb })\end{array}$ & $\begin{array}{c}\text { Nilai } \\
\text { kalor } \\
(\mathrm{cal} / \mathrm{g})\end{array}$ \\
\hline TK:S 50\%:50\% & 5,39 & 2,86 & 32,4 & 59,35 & 6211 \\
TK:S 40\%:60\% & 5,61 & 3,33 & 33,15 & 57,91 & 5999 \\
TK:S 30\%:70\% & 5,84 & 3,38 & 33,17 & 57,61 & 5935 \\
TK:S 20\%:80\% & 6,11 & 3,51 & 33,36 & 57,02 & 5911 \\
TK:S 10\%:90\% & 6,29 & 3,63 & 33,45 & 56,63 & 5824 \\
\hline
\end{tabular}

Berdasarkan tabel 3 terlihat bahwa pada pencampuran sabut dan tempurung kelapa nilai kadar air terendah yaitu pada komposisi sabut 50\% : tempurung 50\% sebesar $5,39 \%$ dan yang kadar air tertinggi yaitu pada komposisi sabut $90 \%$ : tempurung $10 \%$ sebesar $6,29 \%$, Dari hasil tersebut terlihat bahwa semakin besar komposisi tempurung kelapa akan menyebabkan kecenderungan penurunan kadar air, hal ini disebabkan karena kadar air yang terkadung pada tempurung kelapa lebih kecil dibandingkan dengan kadar air yang terkandung pada sabut kelapa, Kadar air dari briket campuran sabut dan tempurung kelapa ini telah memenuhi Standar Briket Nasional yaitu maksimal $8 \%$.

Untuk kadar abu, berdasarkan grafik diatas diketahui bahwa pada pencampuran briket sabut dan tempurung kelapa nilai kadar abu terendah yaitu pada komposisi sabut 50\% : tempurung 50\% sebesar 2,86\% dan yang kadar air tertinggi yaitu pada komposisi sabut $90 \%$ : tempurung $10 \%$ sebesar 3,63\%, Kadar abu adalah jumlah residu anorganik yang dihasilkan dari pengabuan suatu produk, residu tersebut berupa zat - zat mineral yang tidak hilang selama proses pembakaran, Kadar abu akan mempengaruhi kualitas dari briket yang dihasilkan, semakin tinggi kadar abu briket maka semakin kurang baik kualitas dari briket tersebut, karena kadar abu yang tinggi dapat menurunkan nilai kalor briket, Kadar abu dari briket campuran sabut dan tempurung kelapa ini telah memenuhi Standar Briket Nasional yaitu maksimal $8 \%$. 
Untuk kadar zat terbang, berdasarkan grafik diatas diketahui bahwa kadar zat terbang (voleattile matter) juga dipengaruhi oleh kadar air. Kadar air yang tinggi akan menghasilkan kadar zat terbang yang tinggi pula. Kadar volatile matter tertinggi yaitu pada komposisi sabut $90 \%$ : tempurung $10 \%$ sebesar $33,45 \%$ dan kadar volatile matter terendah yaitu pada komposisi sabut $50 \%$ : tempurung $50 \%$. Kadar zat terbang dari briket campuran sabut dan tempurung kelapa ini belum memenuhi Standar Briket Nasional yaitu maksimal 15\%. Tingginya kadar zat terbang pada briket disebabkan olah suhu pada proses pengarangan atau karbonisasi tidak terlalu tinggi. Hal tersebut sesuai dengan pernyataan Sunyata (2004), kadar zat terbang akan semakin kecil jika dilakukan proses pirolisa atau pengarangan dengan suhu yang tinggi [9]. Kadar zat terbang yang tinggi dengan akan menurunkan kualitas briket karena dengan banyaknya zat terbang, maka kandungan karbon semakin kecil sehingga nilai kalor yang dihasilkan semakin rendah serta akan menimbulkan banyaknya asap yang dihasilkan dari pembakarannya (Hendra dan Pari 2000) [10].

Untuk Nilai kalor perlu diketahui dalam pembuatan briket, karena untuk mengetahui nilai panas pembakaran yang dapat dihasilkan oleh briket itu sendiri. Nilai kalor menjadi parameter mutu penting bagi briket sebagai bahan bakar. Semakin tinggi nilai kalor yang dihasilkan oleh bahan bakar briket, maka akan semakin baik pula kualitasnya. Nilai kalor tertinggi pada briket campuran sabut dan tempurung kelapa yaitu pada komposisi sabut 50\% : tempurung 50\% sebesar 6211 $\mathrm{kal} / \mathrm{g}$ dan nilai kalor yang terendah yaitu pada komposisi sabut $90 \%$ : tempurung $10 \%$ sebesar $5824 \mathrm{kal} / \mathrm{g}$, Semakin banyak komposisi tempurung kelapa maka nilai kalornya akan semakin tinggi, dan semakin sedikit komposisi dari tempurung kelapa maka nilai kalor yang dihasilkannya akan cenderung menurun, Hal tersebut karena tempurung kelapa memiliki nilai kalor lebih tinggi dibandingkan dengan sabut kelapa, Tinggi rendahnya nilai kalor dipengaruhi oleh tinggi rendahnya fixed carbon, semakin tinggi fixed carbon maka semakin tinggi nilai kalor yang dihasilkannya. Hal ini sependapat dengan (Triono,2006) nilai kalor briket arang akan tinggi apabila nilai kadar karbon terikat pada briket tinggi [11].

Nilai kalor juga dipengaruhi oleh kada air dan kadar abu yang ada dalam briket arang, semakin rendah kadar air dan kadar abu dalam briket arang maka akan meningkatkan nilai kalor briket arang yang dihasilkan. Sesuai dengan pernyataan Nurhayati (1974) dan Bahri (2008), bahwa nilai kalor dipengaruhi oleh kadar air dan kadar abu yang ada pada briket arang, Apabila semakin tinggi kadar air dan kadar abu, maka nilai kalor yang dihasilkan rendah [12]. Nilai kalor yang dihasilkan dari briket campuran sabut dan tempurung kelapa ini telah memenuhi Standar Briket Nasional yaitu minimal $5000 \mathrm{kal} / \mathrm{g}$.

\subsection{Uji Pembakaran}

Uji pembakaran menggunakan metode WBT (Water Boiling Test), Water Boiling Test merupakan metode simulasi kasar suatu proses pemasakan yang dapat digunakan untuk mengetahui seberapa baik energi panas ditransfer pada alat masak dibandingkan jika menggunakan kompor masak. [13]. Dengan menggunakan metode WBT ini dapat diukur efisiensi pembakaran dari kompor yang menggunakan briket campuran sabut dan tempurung kelapa, Uji pembakaran ini 
hanya dilakukan dengan briket campuran sabut dan tempurung kelapa komposisi optimal yaitu dengan komposisi sabut $50 \%$ : tempurung $50 \%$, Pengujian ini dilakukan dengan menggunakan kompor gasifikasi, Setelah melakukan percobaan didapatkan hasil untuk parameter pengukuran uji pembakaran dari briket campuran sabut dan tempurung kelapa yang ditunjukkan pada tabel 4.

Tabel 4. Hasil Uji Pembakaran

\begin{tabular}{lc}
\hline \multicolumn{2}{c}{ Parameter Pengukuran } \\
\hline Massa bahan bakar $(\mathrm{kg})$ & 0,25 \\
Massa air $(\mathrm{kg})$ & 1 \\
Massa uap air $(\mathrm{kg})$ & 0,15 \\
T air sebelum pembakaran $\left({ }^{\circ} \mathrm{C}\right)$ & 24,3 \\
T air sesudah pembakaran $\left({ }^{\circ} \mathrm{C}\right)$ & 96,4 \\
Lama waktu mendidih $($ menit $)$ & 11,24 menit \\
Efisiensi & $9,86 \%$ \\
\hline
\end{tabular}

Dari perhitungan efisiensi pembakaran didapatkan bahwa nilai efisiensi dari briket campuran sabut dan tempurung kelapa dengan komposisi sabut kelapa 50\% : tempurung kelapa 50\% yaitu sebesar 9,861\%. Efisiensi yang didapat tidak terlalu baik dikarenakan selubung kompor gasifikasi yang terlalu tinggi sedangkan bahan bakar yang digunakan sedikit sehingga proses transfer panas dari bahan bakar menuju panci kurang optimal.

\section{Kesimpulan}

Berdasarkan hasil penelitian yang telah dilakukan maka dapat disimpulkan bahwa perbedaan komposisi campuran pada pembuatan briket sabut dan tempurung kelapa memberikan pengaruh terhadap kadar air, kadar abu, kadar zat terbang (Volattile Matter), kadar karbon padat (Fixed Carbon), dan Nilai Kalor, Penambahan konsentrasi tempurung kelapa akan menurunkan kadar air, kadar abu, kadar zat terbang (Volattile Matter) dan akan menaikan kadar karbon padat dan nilai kalor, Komposisi yang paling optimal pada briket campuran sabut dan tempurung kelapa yaitu pada komposisi Sabut 50\% : Tempurung 50\% karena menghasilkan nilai kalor tertinggi sebesar $6211 \mathrm{kal} / \mathrm{g}$. Efisiensi pembakaran dapat diketahui dengan melakukan uji pembakaran dengan metode WBT (Water Boiling Test), Dengan menggunakan bahan bakar briket campuran sabut dan tempurung kelapa dengan komposisi 50\% : 50\% didapatkan nilai efisiensi pembakaran sebesar 9,861\%. Nilai efisiensi yang didapat kurang baik dikarenakan dimensi kompor gasifikasi tidak sesuai dengan jumlah bahan bakar yang digunakan yang menyebabkan kurang optimalnya transfer panas dari bahan bakar menuju panci.

\section{Daftar Pustaka}

1. Ndraha, Nodali, Uji Komposisi Bahan Pembuat Briket Bioarang Tempurung Kelapa Dan Serbuk Kayu Terhadap Mutu Yang Dihasilkan. Universitas Sumatera Utara. Fakultas Pertanian. Departemen Teknologi pertanian (2009).

2. Silalahi, Penelitian Pembuatan Briket Kayu Dari Serbuk Gergajian Kayu, Hasil Penelitian Industri DEPERINDAG, Bogor, (2000). 
3. M. Yerizam, M. Faizal, M. Novia, Maryono, Sudding, Rahmawati, Preparation and Quality Analysis of Coconut Shell Charcoal Briquette Observed by Starch Concentration, Jurnal Chemica Vol. 14 No. 1 (2013) p. 74 - 83.

4. Sulistyanto, Amin, 2006, Karakteristik pembakaran biobriket campuran batubara dan sabut kelapa, Jurusan Teknik Mesin Fakultas Teknik, Universitas Muhammadiyah Surakarta (2006).

5. Hernandez, Agung, Pembuatan Briket dari Cangkang Kakao dengan menggunakan Perekat Tapioka, Fakultas Teknologi Pertanian, Institut Pertanian Bogor (2013),

6. Gustan, Pari, Teknologi Alternatif Pemanfaatan Limbah Industri Pengolahan Kayu, Program Pascasarjana, Institut Pertanian Bogor (2002).

7. A. Sunyata A, Pengaruh Kerapatan Dan Suhu Pirolisa Terhadap Kualitas Briket Arang Serbuk Kayu Sengon, Fakultas Kehutanan Institute Pertanian (INTAN) Yogyakarta (2004).

8. Y. Yuliah, S. Suryaningsih, K. Ulfi, Penentuan Kadar Air Hilang dan Volatile Matter pada Bio-Briket dari Campuran Arang Sekam Padi dan Batok Kelapa, Jurnal Ilmu dan Inovasi Fisika Vol. 1 No. 1 (2017) p. 51-57.

9. D. Hendra G. Pari G, Penyempurnaan Teknologi Pengolahan Arang, Laporan Penelitian Hasil Hutan, Balai Penelitian dan Pengembangan Kehutanan:Bogor (2000).

10. A. Triono, Karakteristik Briket Arang dari Campuran Serbuk Gergajian Kayu Afrika (Maesopsis eminii EngI,) dan Sengon (Paraserianthes falcataria L,Nielsen) dengan Penambahan Tempurung Kelapa (Cocos nucifera L,) [skripsi], Bogor, Departemen Hasil Hutan, Fakultas Pertanian, Institute Pertanian Bogor (2006).

11. S. Bahri, Pemanfaatan Limbah Industri Pengolahan Kayu untuk Pembuatan Briket Arang dalam Mengurangi Pencemaran Lingkungan di Nangroe Aceh Darussalam, Tesis, USU e-Repository (2008),

12. R. Bailis, D. Ogle, N. MacCarty, Dean, The Water Boiling Test, California (2007).

13. A. F. Mulyadi, I. A. Dewi, P. Deoranto, Utilization of Nypa (Nypa fruticans) Bark for Making Biocharcoal Briquette as Alternative of Energy Sources, ReseachGate Vol. 14 No. 1 (2013) p. 65-72. 